\title{
Steam Temperature Prediction Control Method Using Prediction Model of Multi Heat Exchangers for Thermal Power Plants
}

\author{
Masahide Nomura Student Member (Ibaraki University) \\ Yoshio Sato Member \\ Katsunori Ouchi Member (Hitachi, Ltd.) \\ Ryou Kondo Non-member (Ibaraki University)
}

Keywords : Thermal power plant, Prediction control, Steam temperature control, Kalman Filter, Lumped parameter physical model, Dead time element, Multi heat exchanger model

This paper proposes a new prediction control method for thermal power plants, which is shown on Fig.1.

In the method, steam temperatures are predicted using prediction model of multi heat exchangers, which is shown on Fig.2 and Fig.3. Each model of a heat exchanger consists of a lumped parameter physical model and a dead time element. State variables of the heat exchanger are estimated using a Kalman Filter, and near future changes of steam temperatures are predicted by integrating multi heat exchanger models, and fuel flow and water spray flows are compensated accordingly.

The results of simulation using a practical scale simulator of the thermal power plant show that this method is so practical that changes of main steam temperature ( $\theta$ sMS) are reduced by half comparing with those of PID control method as shown on Fig.4 and Fig.5, in which dot lines show predicted stem temperature values and solid lines show real steam temperature values.

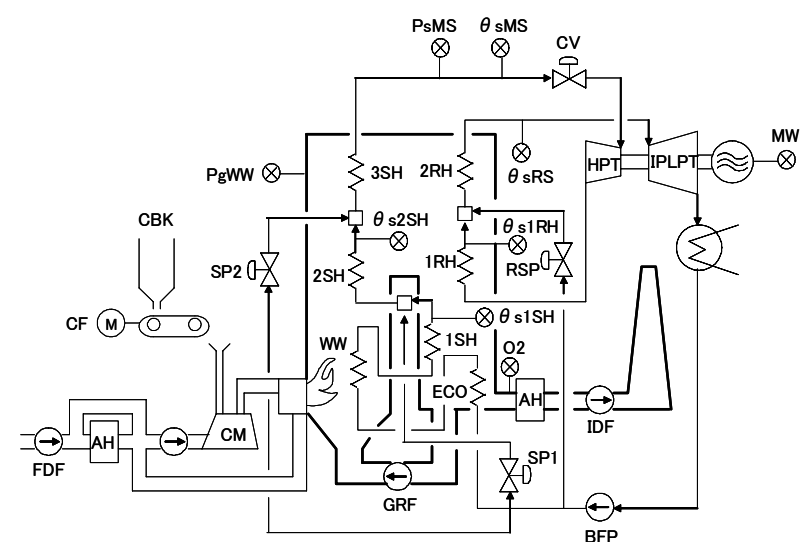

Fig. 1. Structure of coal fired thermal power plant

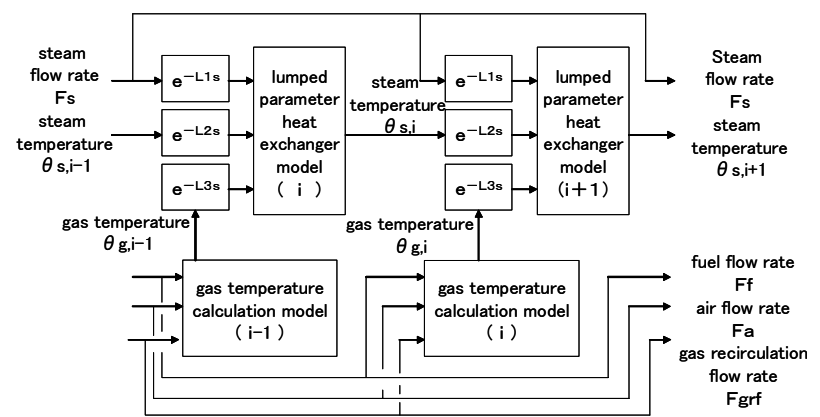

Fig. 2. Structure of steam temparature prediction model

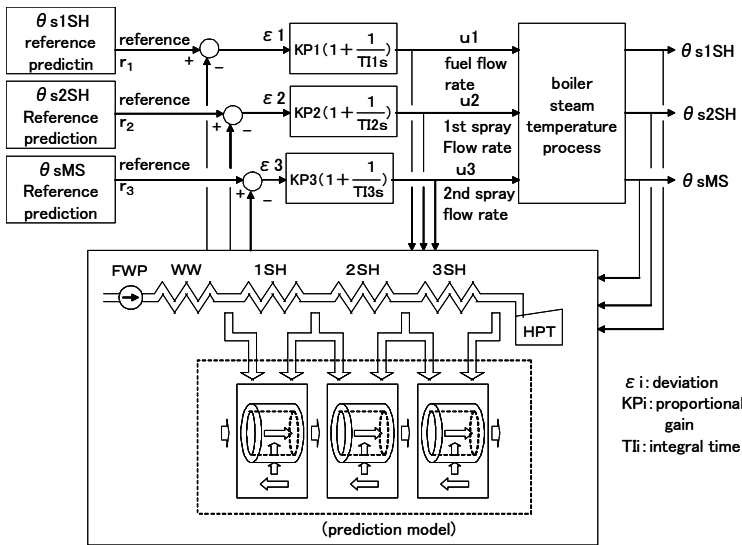

Fig. 3. Structure of steam temperature prediction control system

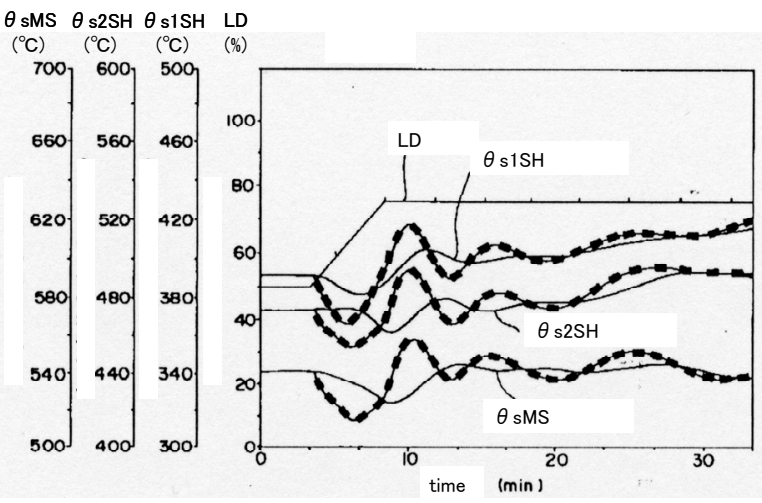

Fig. 4. Simulation results of prediction model for PID control system

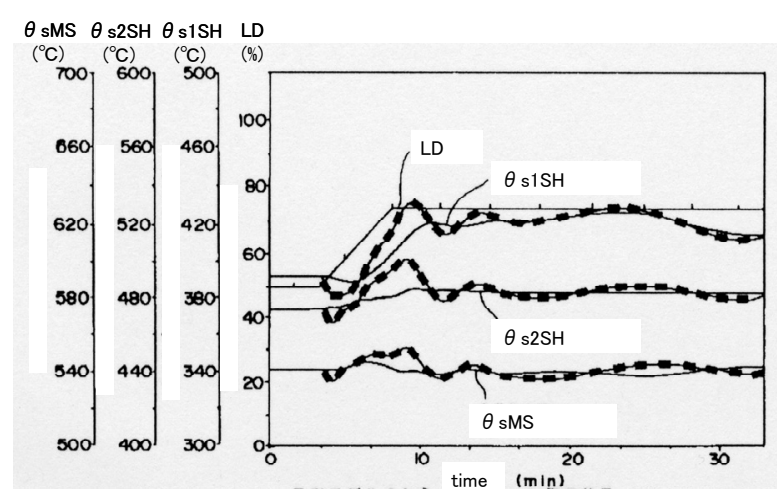

Fig. 5. Simulation results of prediction control system 


\section{多段熱交換器予測モデルを用いた火力発電プラントの}

\section{蒸気温度予測制御方式}

$\begin{array}{lllll}\text { 学生員 野村 } & \text { 政英* } & \text { 正 員 } & \text { 佐藤 } & \text { 美雄 } \\ \text { 正員 大内 } & \text { 和紀** } & \text { 非会員 近藤 良 } & \end{array}$

\section{Steam Temperature Prediction Control Method Using Prediction Model of Multi Heat Exchangers for Thermal Power Plants}

Masahide Nomura*, Student Member, Yoshio Sato, Member, Katsunori Ouchi**, Member, Ryou Kondo*, Non-member

This paper proposes a new prediction control method for thermal power plants. In the method, steam temperatures are predicted using prediction model of multi heat exchangers. Each model of a heat exchanger consists of a lumped parameter physical model and a dead time element. State variables of the heat exchanger are estimated using a Kalman Filter, and near future changes of steam temperatures are predicted by integrating multi heat exchanger models, and fuel flow and water spray flows are compensated accordingly.

The results of simulation using a practical scale simulator of the thermal power plant show that the proposed method is so practical that changes of main steam temperature are reduced by half comparing with those of PID control method.

キーワード : 火力発電プラント, 予測制御, 蒸気温度制御, カルマン・フィルタ, 集中定数化物理モデル, 無駄時間要素, 多段熱交 換器モデル

Keywords : Thermal power plant, Prediction control, Steam temperature control, Kalman Filter, Lumped parameter physical model, Dead time element, Multi heat exchanger model

\section{1. 緒言}

火力発電プラントの制御上の特徵は, 蒸気温度の応答遅 れが大きいことであり, 主蒸気温度の時定数は, 10 分〜20 分程度ある。従って, 通常のフィードバック制御では, 負 荷指令が大きく変化すると, 主蒸気温度が大きく変動し, タービンの熱ストレスを増大させ，タービンの寿命が減少 すると言う問題がある。このため，火力プラントは，制御 が難しいと言われている。

一方，火力プラント制御装置(APC)は，マイクロ・コンピ ユータを利用した分散型ディジタル制御装置が主流であ $り^{(1) \sim(4)}$, 複雑かつ高度な制御方式の導入が可能である。

そこで，火力プラントの制御上の問題に対処するため, 火力プラントのモデルを制御システムに内蔵し，このモデ ルを用いて，プラントの将来の動きを予測し，この予測結

* 茨城大学大学院理工学研究科

产316-8511 茨城県日立市中成沢町 4-12-1

Graduate School of Science and Engineering, Ibaraki University,

4-12-1 Nakanarisawa, Hitachi 316-8511

** 日立製作所大多加事業所

厂319-1293 茨城県日立市大夕力町 5-2-1

Omika Works, Hitachi, Ltd.,

5-2-1 Omika, Hitachi 319-1293
果に基づいて操作量を決定する比例 ・ 積分形予測制御方式 が著者等により提案されている(5) (8)。この制御方式で用い られている予測モデルは, 最終段過熱器の特性を物理式で 表した集中定数化モデルであり, カルマン・フィルタ ${ }^{(9)}$ と組 み合わせた予測方式を採用している(5) (7)。このモデルは, 前段過熱器の出口蒸気温度, 寸なわち最終段過熱器の入口 蒸気温度を外乱として, 最終段過熱器の出口温度, 寸なわ ち主蒸気温度を予測している。また，この他に，火力プラ ントの蒸気温度制御に統計モデルを用いた制御方式も提案 されている(10) (14)。

なお，最終段過熱器の物理式モデルを利用した比例・積 分形予測制御方式は，著者等が実用化したボイラ起動時の 火炉水壁出口流体温度の比例 ・ 積分形予測制御方式(15)を発 展させた制御方式である。すなわち, 火炉水壁出口流体温 度の比例・積分形予測制御方式では, 制御量, すなわち火 炉水壁出口蒸気温度の予測に，変化率を利用しているが， 最終段過熱器の物理式モデルを利用した比例・積分形予測 制御方式では, 最終段過熱器のモデルにより主蒸気温度を 予測している点が技術的に進んでいる。

ところで，最近，電力需要の増大と共に，昼夜の電力需 
要の格差も増大してきている。そのため, 大容量の火力プ ラントでも, 負荷追従運転 (中間負荷運用) 及びDSS (Daily Start Stop）運転が要求されるようになってきている。これら の要求に伴い, 火力プラント制御システムに対して, 負荷 追従制御特性及び起動時制御特性の向上が求められてい る。しかし，上記従来の予測制御(5) (7)では，これに対して 十分に対応することが困難と考えられる。それは, 従来の 予測制御では，上記文献 ${ }^{(5)}$ (7)に記載されているように，火 カプラントの最終段過熱器のみの特性を物理式で表した集 中定数化モデルで近似した予測モデルを使用していること による。

火力プラントは, 節炭器, 火炉水壁, 1 次過熱器, 2 次過 熱器, 3 次過熱器等の複数の熱交換器で構成されている。こ れらの熱交換器の中を, 上流から下流に向かって水が流れ るうちに，燃焼ガスのエネルギを吸収して蒸気となり，更 に過熱蒸気となる。すなわち, 火力プラントは, 分布定数 系である。それにも拘らず，上記従来技術(5) (7)では，火力 プラントの最終段過熱器のみを集中定数化モデルで近似 し，このモデルにより火力プラントの近い将来の動きを予 測して，この予測結果に基づいて操作量を決定している。 そのため, 予測に, 前段過熱器の出口蒸気温度の変化を考 慮できないので，予測性能及び制御性の向上を望めないと 言う問題がある。

また，統計モデルを用いた制御方式(10) (14)では，負荷追従 運転やDSS 運転のように, 負荷が急速に大きく変化する場 合, プラントの非線形特性により運転中に特性が大幅に変 化したり，炭種により時間的にプラント特性が変化するた め，適用に限界があると思われる。例えば，中村等 ${ }^{(10)}$ は， 擬似ランダム信号を利用して, 統計モデルにより火力プラ ントの蒸気温度系を幾つかの負荷レベルでオフライン同定 し，最適制御により制御性を改善している。負荷レベル間 の特性はモデルパラメータの内挿により求めて, 非線形特 性にはある程度対応できているが，プラント特性の時間的 変化の対応には限界がある。なお, 著者等 ${ }^{(11)}$ は, 擬似ラン ダム信号により統計モデルをオンラインで同定する方式を 導入し, 非線形特性と時間的特性変化に対応したが，適応 に限界があった。松村等 ${ }^{(12)}$ は，パラメータが負荷に比例す る統計モデルを導入して，オンライン同定により非線形特 性と時間的特性変化に対応しようとしたが，やはり適応に 限界があった。豊田等 ${ }^{(13)}$ やPeng 等 ${ }^{(14)}$ は, 非線形統計モデル を導入して，擬似ランダム信号を利用し，蒸気温度系の特 性をオフライン同定して, 精度の良い非線形統計モデルを 得て，予測制御により制御性を改善しているが，時間的な 特性変化への対応には限界があると思われる。

本論文では，複数の熱交換器から構成され，本来分布定 数系である火力プラントの非線形分布定数系特性が精度良 く模擬できる予測モデル, すなわち, 多段熱交換器予測モ デルを立案する。次に，そのモデルとカルマン・フィルタ を用いて, 状態推定及びモデル化誤差を同定し, それに基 づいた蒝気温度予測制御方式を立案し, その妥当性をシミ
ユレーションにより確認する。

先ず 2 章で, 火力発電プラント及びその制御システムの 概要について説明する。続いて 3 章で, 火力プラントの新 予測モデル（以下，多段熱交換器予測モデルを新予測モデ ルと称する）の設計思想について説明し，次に 4 章で，こ の新予測モデルとカルマン・フィルタを組み合わせた予測 方式について説明する。更に 5 章で, この予測モデルを用 いた予測制御方式について説明し，6 章でシミュレーション により評価する。なお, シミュレーションでは, 変圧貫流 ボイラの実規模シミュレータを用い, 先ず, 現在值を用い たフィードバック制御 (PID 制御) 時の新予測モデルの予測 性能を評価する。続いて, 新予測モデルの予測值を用いた 予測制御方式の制御性能を評価する。

なお，超リアルタイムシミュレーションコントロール (SRTC) 方式(16)(17)が, 提案されているが, この方式は, ボ イラ動特性モデルを制御システムに組み込んで, 1 分先まで の負荷変動の予測值に基づいて, 複数の高速プロセッサに より蒸気温度が変動しないような操作量を計算する方式で ある。1 分先の負荷変動の予測值及び高速プロセッサが必要 であり, 負荷変動の予測精度に依存すると共に, コントロ ーラが高価になると言う問題が有る。これに対して, 本論 文で提案している新予測制御方式では，普通のコントロー ラに熱交換器モデルを組み込んで予測制御ができ, 負荷変 動の予測值も不要である。

また，非線形モデルベースの予測制御装置(NMPC) ${ }^{(18)}$ が， 提案されているが，ボイラ起動時の最適制御に使用されて おり，省燃料制御や起動時間の短縮等を目的に最適制御す る方式であり, 制御周期も 1 分となっている。このため, 急速で大幅な負荷変動運転における蒸気温度制御には適用 上限界があると思われる。これに対して, 本論文で提案し ている新予測制御方式では, 制御周期が数秒で数分先の蒸 気温度を予測し，急速大幅な負荷変動にも十分対応できる。

ただ，豊田等が，火力プラントの脱硝設備に対して，非 線形統計モデルを改良して, 非線形モデルベースの予測制 御装置を開発している(19)。蒸気温度制御系とは制御対象が 異なるが，実機に適用し，成果を上げている。

\section{2. 火力発電プラント及びその制御システムの概 要}

本章では, 火力発電プラント及びその制御システムの概 要について説明する。

先ず，制御対象である火力発電プラントであるが，図 1 に石炭焚き火力プラントの例を示す。押し込みファン (FDF) からの空気は, 空気予熱器 $(\mathrm{AH})$ を通って加熱され, 1 次 空気ファンによって加速されて, 石炭ミルに送風される。 一方, 石炭バンカ (CBK) 内の石炭は, 給炭機モータによ り駆動される給炭機により, 石炭ミル内に運搬される。石 炭ミルによって微粉状となった石炭は, 空気流と共にボイ ラ内のバーナに送られ, ここで燃焼する。節炭器 (ECO), 火炉水壁（WW）及び 1 次過熱器（1SH）を通った水は，こ 
の燃焼ガスにより蒸気となる。この蒸気は, 1 次スプレ (SP1) を通り, 2 次過熱器 (2SH) で過熱されて, 2 次スプレ (SP2) を通った後, 3 次過熱器 (3SH) で更に過熱されて, 主蒸気 配管及び主蒸気加減弁を通って, 高圧タービン（HPT）に入 る。

高圧タービンを出た蒸気は, 1 次再熱器 $(1 \mathrm{RH})$ 及び 2 次 再熱器 (2RH)により再過熱され, 中・低圧タービン (IP\&LPT) に送られる。発電機は, 高圧タービンと中・低圧タービン とにより駆動され発電する。中・低圧タービンを出た蒸気 は, 復水器により復水される。この復水は, 給水ポンプ (BFP) により再びボイラの節炭器に送られる。また, 給水ポンプ を出た給水は, 1 次スプレ制御弁および 2 次スプレ制御弁を 介して，1 次スプレ及び 2 次スプレに送られる。同様に，給 水ポンプを出た給水は, 再熱スプレ制御弁を介して, 再熱 スプレ（RSP）に送られる。なお，ボイラには，燃焼ガスを 再循環させるガス再循環ファン（GRF）が設けられている。 また, ボイラには, 火炉圧力を制御するための誘引ファン (IDF）が設けられている。

更に, この火力プラントには, プラントの状態を検出す るための各種センサが設けられている。すなわち, 図 1 に 示すように, 主蒸気圧力 (PsMS), 1 次過熱器出口蒸気温度 $(\theta$ $\mathrm{s} 1 \mathrm{SH})$, 排ガス中の $\mathrm{O}_{2}$ 量 $\left(\mathrm{O}_{2}\right)$, 火炉圧力 $(\mathrm{PgWW}), 2$ 次過熱 器出口蒸気温度 $(\theta \mathrm{s} 2 \mathrm{SH})$, 主蒸気温度 $(\theta \mathrm{sMS})$, 再熱蒸気温 度 $(\theta \mathrm{sRS}), 1$ 次再熱器出口蒸気温度 $(\theta \mathrm{s} 1 \mathrm{RH})$, 及び発電量 (MW)を検出するセンサが設けられている。図示していない が, 1 次過熱器, 2 次過熱器及び 3 次過熱器には, それぞれ 入口または出口に, 蒸気流量, 圧力及び温度を測定する流 量, 圧力及び温度センサが設けられている。同様に, 1 次再 熱器及び 2 次再熱器についても, それぞれ入口または出口 に, 蒸気流量, 圧力及び温度を測定する流量, 圧力及び温 度の各センサが設けられている。

火力プラント制御システムは, 上記のセンサ情報に基づ いて, 火力プラントを制御する。火力プラント制御システ ムの例を図 2 に示す。この図から分かるように, 火力プラ ント制御システムは, 機能的に, マスタ制御部とサブルー プ制御部とで構成されている。

マスタ制御部は, 発電量, 主蒸気圧力, 1 次過熱器出口蒸 気温度, ガス $\mathrm{O}_{2}$, 火炉圧力, 2 次過熱器出口蒸気温度, 主 蒸気温度, 及び再熱蒸気温度の 8 個の制御量を制御する。 このための操作量は, 主蒸気流量, 給水流量, 燃料流量, 空気流量, 排ガス流量, 1 次スプレ流量, 2 次スプレ流量, 再熱スプレ流量及び再循環ガス流量の 8 個であり, これら の操作量は, サブループ制御部により制御される。すなわ ち, 火力プラントは, 多入力多出力系であり, 火力プラン 卜制御システムは, 中央給電指令所からの負荷指令に従っ て発電量を変化させると共に, 他の制御量の変動を抑制す ることが要求されている。

火力プラントの制御量のうち, 制御が難しいのは, 蒸気 温度である。例えば, 1 次過熱器出口蒸気温度, 2 次過熱器 出口蒸気温度, 主蒸気温度及び再熱蒸気温度の 4 つがそれ

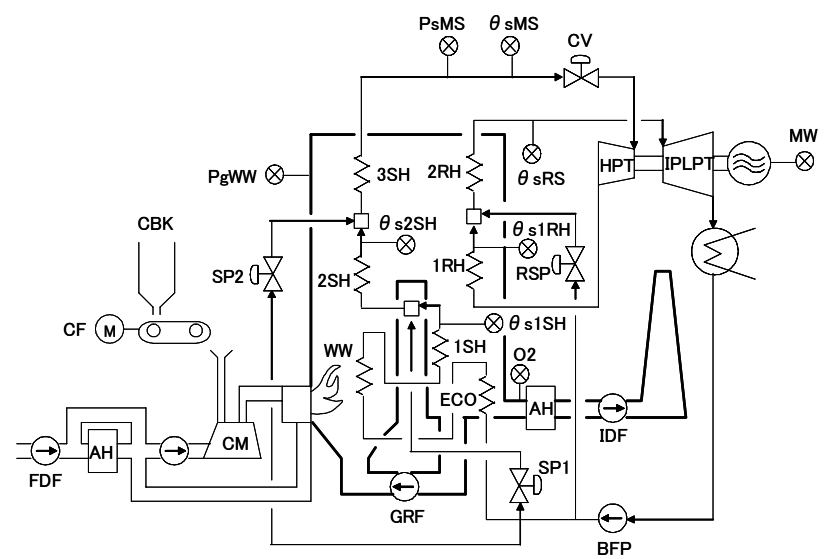

図 1 石炭焚き火力プラントの例

Fig. 1. Structure of coal fired thermal power plant.

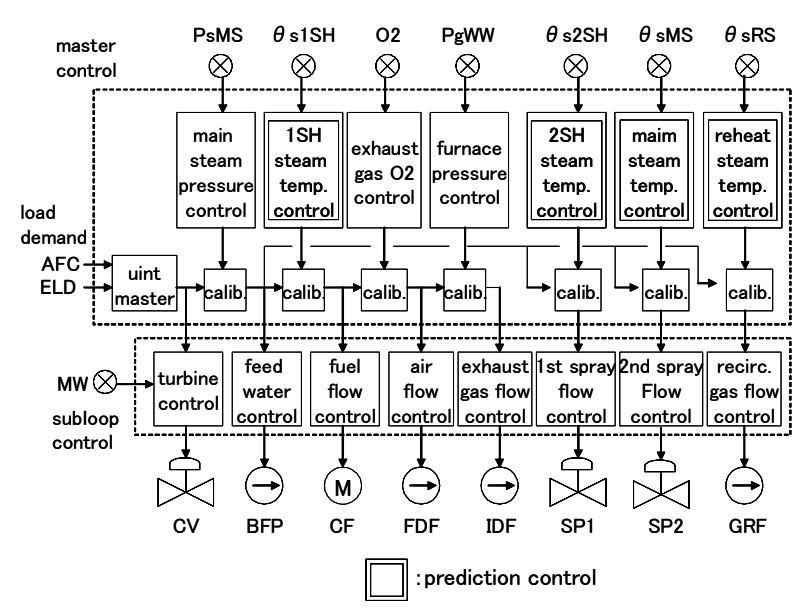

図 2 火力プラント制御システム

Fig. 2. Control system of thermal power plant.

である。また, これらの蒸気温度の制御のために, 燃料流 量, 1 次スプレ流量, 2 次スプレ流量及びガス再循環流量の 4 つの操作量がある。図 2 から分かるように, 本論文では, これらの蒸気温度の制御に予測值を用いて予測制御するよ うにしたものである。そして, その際に, 従来にない予測 モデル，すなわち，新予測モデルを用いたことに特徴があ る。

\section{3. 多段熱交換器予測モデル}

蒸気温度予測制御では, 蒸気温度系のモデル，すなわち， 蒸気温度予測モデルを使用して, 蒸気温度の近い将来值を 予測する必要がある。本章では, この蒸気温度予測モデル の新方式について検討する。

火力プラントの熱交換器の全体構成は, 図 1 に概略を示 したが, 次に, このような熱交換器の概略構成を前提にし て, 図 3 に各熱交換器の構成を示寸。この図から分かるよ うに, 熱交換器の管壁を構成するメタルが, コイル状に分 布配置され, このメタルの内側を水・蒸気が流れ $(\mathrm{Fs})$, 外 側をガスが流れる（Fg）うちに，先ず，ガスからメタルへ 
熱が伝わり，次に，メタルを介して水・蒸気に熱が伝達さ れる。すなわち, 入口ガス温度 $\theta \operatorname{gIN}$ のガスが熱交換器のメ タルと接触して, メタルに熱を与えて, 出口ガス温度 $\theta \mathrm{g}$ と なって流出する。一方, 入口蒸気温度 $\theta \operatorname{sIN}$ の蒸気がメタル と接触して，メタルから熱を受けて，出口温度 $\theta \mathrm{s}$ となって 流出する。これから分かるように，1つの熱交換器が，それ 自身, 分布定数系を構成している。

蒸気温度予測モデルは, 図 3 に示す火力プラントの各熱 交換器を, 図 4 に示すように, 各熱交換器を無駄時間要素 と物理式に基づく集中定数化モデルとの組み合わせにより モデル化し, それらの各熱交換器のモデルを結合して構成 している。すなわち, 火力プラントの各熱交換器は, 水・ 蒸気系で，上流側から下流側に順次接続され，水・蒸気の 状態変化が上流側から下流側に伝達される構成となってい て, 蒸気温度予測モデルは, これらの各熱交換器の上記モ デルを統合して使用し，蒸気温度の近い将来值を予測する。

集中定数化モデルは, 各熱交換器の水・蒸気系及びガス 系に対してエネルギ保存式により表される。また，ガス温 度については, ガス温度計算モデルが用いられる。このガ ス温度計算モデルは，燃料流量 Ff，空気流量 $\mathrm{Fa}$ 及びガス再 循環流量 Fgrfに基づいて，ガス温度を計算する。

図 4 に示す 2 段の熱交換器モデルの内，当該熱交換器(i) の集中定数化モデルには，次式に示すように，前段熱交換 器( $i-1)$ (図示していない) の蒸気流量 Fs,i-1, 出口蒸気温 度 $\theta \mathrm{s}, \mathrm{i}-1$ 及び出口ガス温度 $\theta \mathrm{g}, \mathrm{i}-1$ がそれぞれの無駄時間 要素を介して入力される。当該熱交換器(i)の集中定数化モデ ルは, これらに基づいて出口蒸気温度 $\theta \mathrm{s}, \mathrm{i}$ を計算し, 出力 する。

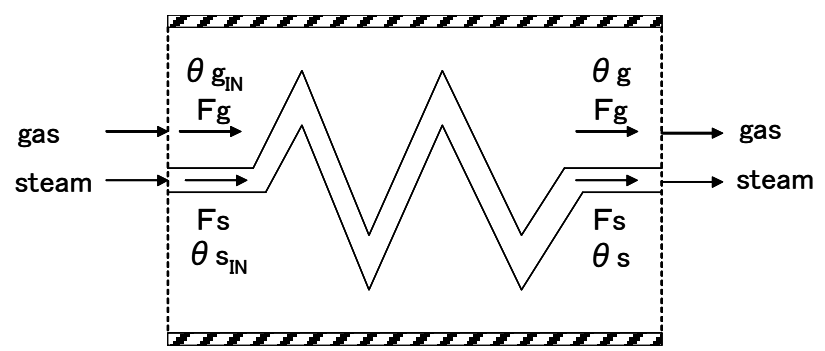

図 3 各熱交換器の構成

Fig. 3. Schematics of a heat exchanger.

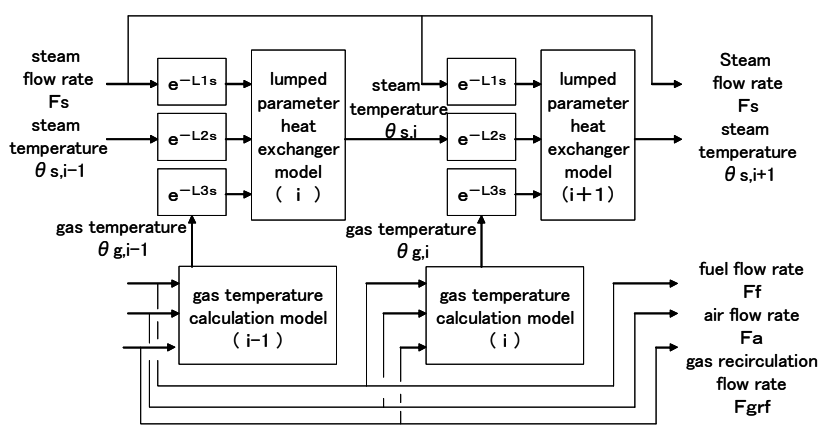

図 4 蒸気温度予測モデル

Fig. 4. Structure of steam temparature prediction model.

$$
\begin{gathered}
\text { Fs, } \mathrm{i}=\exp \left(-\mathrm{L}_{1}, \mathrm{i} \cdot \mathrm{s}\right) \cdot \mathrm{Fs}, \mathrm{i}-1 \\
\theta \sin , \mathrm{i}=\exp \left(-\mathrm{L}_{2}, \mathrm{i} \cdot \mathrm{s}\right) \cdot \theta \mathrm{s}, \mathrm{i}-1 \\
\theta \text { gin, } \mathrm{i}=\exp \left(-\mathrm{L}_{3}, \mathrm{i} \cdot \mathrm{s}\right) \cdot \theta \mathrm{g}, \mathrm{i}-1
\end{gathered}
$$

ここで,

Fs,i : 管内部流体（水・蒸気）の流量 $(\mathrm{kg} / \mathrm{s})$

$\theta \sin , \mathrm{i}$ : 管内部流体（水・蒸気）の入口温度 $\left({ }^{\circ} \mathrm{C}\right)$

$\theta \mathrm{s}, \mathrm{i}$ : 管内部流体（水・蒸気）の出口温度 $\left({ }^{\circ} \mathrm{C}\right)$

$\theta$ gin,i : 管外部流体（ガス）の入口温度 $\left({ }^{\circ} \mathrm{C}\right)$

$\theta \mathrm{g}, \mathrm{i}$ : 管外部流体 (ガス) の出口温度 $\left({ }^{\circ} \mathrm{C}\right)$

$\mathrm{L}_{1}, \mathrm{i}$ : 管内部流体（水・蒸気）の流量の無駄時間 $(\mathrm{s})$

$\mathrm{L}_{2}, \mathrm{i}$ : 管内部流体（水・蒸気）の入口温度の無駄時間(s)

$\mathrm{L}_{3}, \mathrm{i}$ : 管外部流体（ガス）の入口温度の無駄時間(s)

$\mathrm{i}: \mathrm{i}$ 番目の熱交換器

$\mathrm{s}:$ ラプラス演算子

また，後段熱交換器(i+1)の集中定数化モデルには，当該 熱交換器(i)から出力された蒸気流量 Fs, i, 蒸気温度 $\theta \mathrm{s}, \mathrm{i}$ 及び ガス温度 $\theta \mathrm{g}, \mathrm{i}$ が，それぞれの無駄時間を介して入力され， 集中定数化モデルは, 同様にして, 蒸気温度 $\theta \mathrm{s}, \mathrm{i}+1$ を計算 し, 出力する。なお, 図 4 では, 熱交換器を 2 段分示して いるが，本方式は，これに限定されない。また，図 4 で, 無駄時間要素で表現している要素は，実際の予測モデルで は, 次式に示すように, 1 次遅れ要素をカスケードに接続し て構成した 3 次遅れ要素で近似している。

$$
\begin{aligned}
& \exp \left(-\mathrm{L}_{1}, \mathrm{i} \cdot \mathrm{s}\right)=1 /\left(1+\mathrm{T}_{1}, \mathrm{i} \cdot \mathrm{s}\right)^{3} \\
& \exp \left(-\mathrm{L}_{2}, \mathrm{i} \cdot \mathrm{s}\right)=1 /\left(1+\mathrm{T}_{2}, \mathrm{i} \cdot \mathrm{s}\right)^{3} \\
& \exp \left(-\mathrm{L}_{3}, \mathrm{i} \cdot \mathrm{s}\right)=1 /\left(1+\mathrm{T}_{3}, \mathrm{i} \cdot \mathrm{s}\right)^{3}
\end{aligned}
$$

ここで, $\mathrm{T}_{1, \mathrm{i}}, \quad \mathrm{T}_{2, \mathrm{i}}, \quad \mathrm{T}_{3, \mathrm{i}}$ : 時定数 $(\mathrm{s})$

各熱交換器における集中定数化モデルは, 図 5 に示すモ デルを想定して, エネルギ保存の法則により導かれる。図 5 に示すモデルは, 熱交換器の管壁を構成するメタルの一方 側に水・蒸気が流れ(Fs), 他方側にガスが流れて $(\mathrm{Fg})$, ガス から蒸気へメタルを介して熱が伝達される状態を想定して いる。ここでは, 入口ガス温度 $\theta$ gin のガスが熱交換器のメ タルと接触して, メタルに伝熱量 $\mathrm{Q}$ の熱を与えて, 出口ガ ス温度 $\theta \mathrm{g}$ となって流出する。一方, 入口水・蒸気温度 $\theta \sin$

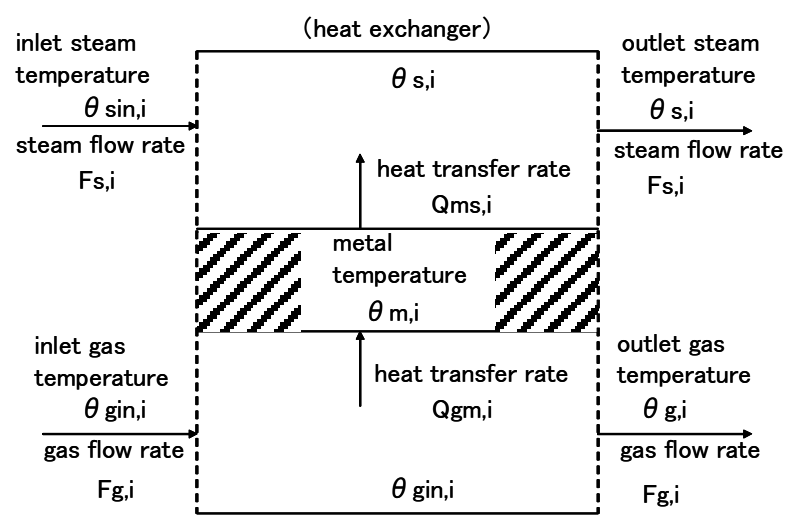

図 5 各熱交換器における集中定数化モデル

Fig. 5. Structure of lumped parameter model for heat exchanger. 
の水・蒸気がメタルと接触して，メタルから伝熱量 Q の熱 を受けて, 出口水・蒸気温度 $\theta \mathrm{s}$ となって流出する。ガス流 量 Fg, すなわち, ボイラ・ガス流量 FgBF は, 後述するよ うに, 空気流量 $\mathrm{Fa}$, 燃料流量 Ff 及び再循環ガス流量 Fgrf の合計である。なお，集中定数化モデルでは，ガス，メタ ル，水・蒸気において，温度は，一様と仮定する。

このような考えの物理モデルに基づいて，集中定数化モ デル式は，エネルギ保存の法則から導かれる次式により表 される。

$$
\mathrm{Vs}, \mathrm{i} \cdot \gamma \mathrm{s}, \mathrm{i} \cdot \mathrm{dHs}, \mathrm{i} / \mathrm{dt}=(\mathrm{Hsin}, \mathrm{i}-\mathrm{Hs}, \mathrm{i}) \cdot \mathrm{Fs}, \mathrm{i}
$$$$
+ \text { Ams, } \mathrm{i} \cdot \alpha \mathrm{ms}, \mathrm{i} \cdot(\theta \mathrm{m}, \mathrm{i}-\theta \mathrm{s}, \mathrm{i})
$$

$\mathrm{Mm}, \mathrm{i} \cdot \mathrm{Cm}, \mathrm{i} \cdot \mathrm{d} \theta \mathrm{m}, \mathrm{i} / \mathrm{dt}=\mathrm{Agm}, \mathrm{i} \cdot \alpha \mathrm{gm}, \mathrm{i} \cdot(\theta$ gin $, \mathrm{i}-\theta \mathrm{m}, \mathrm{i})$

$$
-\mathrm{Ams}, \mathrm{i} \cdot \alpha \mathrm{ms}, \mathrm{i} \cdot(\theta \mathrm{m}, \mathrm{i}-\theta \mathrm{s}, \mathrm{i})
$$

ここで,

Vs,i : 熱交換器の管内部流体（水・蒸気）の容積 $\left(\mathrm{m}^{3}\right)$

$\gamma \mathrm{s}, \mathrm{i}$ : 管内部流体 (水・蒸気) の比重量 $\left(\mathrm{kg} / \mathrm{m}^{3}\right)$

$\mathrm{Hs}, \mathrm{i}$ : 管内部流体（水・蒸気）の出口エンタルピ $(\mathrm{kcal} / \mathrm{kg})$

$H \sin , \mathrm{i}$ : 管内部流体 (水・蒸気) の入ロエンタルピ $(\mathrm{kcal} / \mathrm{kg}$ )

Fs,i : 管内部流体（水・蒸気）の流量 $(\mathrm{kg} / \mathrm{s})$

Ams,i : 管メタルから管内部流体（水・蒸気）への伝熱面 積 $\left(\mathrm{m}^{2}\right)$

Agm,i : 管外部流体 (ガス) から管メタルへの伝熱面積 $\left(\mathrm{m}^{2}\right)$ $\alpha \mathrm{ms}, \mathrm{i}$ : 管メタルから管内部流体（水・蒸気）への対流熱 伝達率 $\left(\mathrm{kcal} /\left(\mathrm{m}^{2} \cdot{ }^{\circ} \mathrm{C} \cdot \mathrm{s}\right)\right)$, Fs,i に依存するものと 仮定

$\alpha$ gm,i : 管外部流体 (ガス) から管メタルへの対流熱伝達 率 $\left(\mathrm{kcal} /\left(\mathrm{m}^{2} \cdot{ }^{\circ} \mathrm{C} \cdot \mathrm{s}\right)\right), \mathrm{FgBF}$ に依存するものと仮定

$\mathrm{Mm}, \mathrm{i}$ : 熱交換器の管メタルの重量 $(\mathrm{kg})$

$\mathrm{Cm}, \mathrm{i}:$ 管メタルの比熱 $\left(\mathrm{kcal} /\left(\mathrm{kg} ・{ }^{\circ} \mathrm{C}\right)\right)$

$\theta \mathrm{m}, \mathrm{i}$ : 管メタルの温度 $\left({ }^{\circ} \mathrm{C}\right)$

$\theta \mathrm{s}, \mathrm{i}$ : 管内部流体 (水・蒸気) の出口温度 $\left({ }^{\circ} \mathrm{C}\right)$

$\theta$ gin,i : 管外部流体 (ガス) の入口温度 $\left({ }^{\circ} \mathrm{C}\right.$ )

$\mathrm{i}: \mathrm{i}$ 番目の熱交換器

また, 熱交換器の管外部流体 (ガス) は, 管内部流体 (水・ 蒸気）及びメタル部の応答に比べると，その応答が極めて 速いので，ガス系は，静的にエネルギ保存則が成り立つも のとして次式で表される。

$\Theta \mathrm{gIN}, \mathrm{i}=(\eta \cdot \mathrm{Hu} \cdot \mathrm{Ff}+\mathrm{Ha} \cdot \mathrm{Fa}+\mathrm{Hgrf} \cdot$ Fgrf-Qww-QHEX,i $)$ $/(\mathrm{Cpg} \cdot \mathrm{FgBF})$

$\mathrm{Qww}=\beta \mathrm{ww}[\{(\eta \cdot \mathrm{Hu} \cdot \mathrm{Ff}+\mathrm{Hu} \cdot \mathrm{Fa}+\mathrm{Hgrf} \cdot \mathrm{Fgrf})$ $/(\mathrm{Cpg} \cdot \mathrm{FgBF})+273\} / 100]^{4}$

$\mathrm{FgBF}=\mathrm{Ff}+\mathrm{Fa}+\mathrm{Fgrf}$

ここで,

$\mathrm{Hu}:$ 燃料発熱量 $(\mathrm{kcal} / \mathrm{kg})$

$\mathrm{Ff}:$ 燃料流量 $(\mathrm{kg} / \mathrm{s})$

$\mathrm{Ha}$ : 空気エンタルピ $(\mathrm{kcal} / \mathrm{kg})$

$\mathrm{Fa}$ : 空気流量 $(\mathrm{kg} / \mathrm{s})$

Hgrf : 再循環ガスのエンタルピ $(\mathrm{kcal} / \mathrm{kg})$

Fgrf : ガス再循環流量 $(\mathrm{kg} / \mathrm{s})$

$\eta$ : 燃料発熱効率(一), Ff に依存するものと仮定
Cpg：ガス比熱 $\left(\mathrm{kcal} /\left(\mathrm{kg} \cdot{ }^{\circ} \mathrm{C}\right)\right), \mathrm{Ff}$ に依存するものと仮定

$\beta \mathrm{ww}$ ：火炉輻射熱伝達係数 $(一)$, Ff に依存するものと仮 定

$\mathrm{FgBF}:$ ボイラ・ガス流量 $(\mathrm{kg} / \mathrm{s})$

Qww：火炉水壁熱吸収量 $(\mathrm{kcal} / \mathrm{s})$

$\mathrm{Q}_{\mathrm{HEX}}, \mathrm{i}$ : 火炉水壁以外のガス側上流熱交換器の総熱吸収量 $(\mathrm{kcal} / \mathrm{s}), \mathrm{Ff}$ に依存するものと仮定

なお, 前記空気エンタルピ $\mathrm{Ha}$ は, 空気の比熱を $\mathrm{Cpa}$, 空気 の温度を $\theta \mathrm{a}$ とすると, 次式で与えられる。

$\mathrm{Ha}=\mathrm{Cpa} \cdot \theta \mathrm{a}$

また, 再循環ガスのエンタルピ Hggrf は, ガスの比熱を Cpg, 節炭器付近のガス温度を $\theta$ geco とすると, 次式で与えられ る。

Hggrf $=$ Cpg $・ \theta$ geco

水・蒸気系の伝熱を定圧過程と近似すると, 次式が成り 立つ。なお, 以下では, 熱交換器の番号 $\mathrm{i}$ は, 省略する。

$\mathrm{dHs} / \mathrm{dt}=\{\partial \mathrm{Hs} / \partial \theta \mathrm{s}\} \mathrm{p} \cdot \mathrm{d} \theta \mathrm{s} / \mathrm{dt}=\mathrm{Cps} \cdot \mathrm{d} \theta \mathrm{s} / \mathrm{dt} \cdots \cdot .(14)$

$\mathrm{Hs}=\{\partial \mathrm{Hs} / \partial \theta \mathrm{s}\} \mathrm{p} \cdot \theta \mathrm{s}+\mathrm{Hs}_{0}=\mathrm{Cps} \cdot \theta \mathrm{s}+\mathrm{Hs}_{0} \cdots \cdots \cdots(15)$

$\mathrm{Cps}=\{\partial \mathrm{Hs} / \partial \theta \mathrm{s}\} \mathrm{p}$

ここで,

Cps : 定压比熱 $\left(\mathrm{kcal} /\left(\mathrm{kg} \cdot{ }^{\circ} \mathrm{C}\right)\right)$

$\mathrm{Hs}_{0}$ : 基準エンタルピ $(\mathrm{kcal} / \mathrm{kg})$

\{ \}p：添え字 $\mathrm{p}$ は，定圧を表わす

なおここでは，(16)式を次式により近似する。

$\mathrm{Cps}=(\Delta \mathrm{Hs} / \Delta \theta \mathrm{s}) \mathrm{p}$

ここで,

$\Delta:$ 微小変化分

(14), (15)式を( 7 )式に代入して, 整理すると次式が得られ る。

$$
\begin{aligned}
\mathrm{d} \theta \mathrm{s} / \mathrm{dt}= & -(\mathrm{Cps} \cdot \mathrm{Fs}+\alpha \mathrm{ms} \cdot \mathrm{Ams}) /(\mathrm{Vs} \cdot \gamma \mathrm{s} \cdot \mathrm{Cps}) \cdot \theta \mathrm{s} \\
& +\alpha \mathrm{ms} \cdot \mathrm{Ams} /(\mathrm{Vs} \cdot \gamma \mathrm{s} \cdot \mathrm{Cps}) \cdot \theta \mathrm{m} \\
& +\mathrm{Fs} /(\mathrm{Vs} \cdot \gamma \mathrm{s} \cdot \mathrm{Cps}) \cdot\left(\mathrm{Hsin}-\mathrm{Hs}_{0}\right) \cdots \cdots \cdots(18)
\end{aligned}
$$

また, $(8)$ 式を変形すると, 次式が得られる。

$\mathrm{d} \theta \mathrm{m} / \mathrm{dt}=\alpha \mathrm{ms} \cdot \mathrm{Ams} /(\mathrm{Mm} \cdot \mathrm{Cm}) \cdot \theta \mathrm{s}$

$$
\begin{aligned}
& -(\alpha \mathrm{gm} \cdot \mathrm{Agm}+\alpha \mathrm{ms} \cdot \mathrm{Ams}) /(\mathrm{Mm} \cdot \mathrm{Cm}) \cdot \theta \mathrm{m} \\
& +(\alpha \mathrm{gm} \cdot \mathrm{Agm}) /(\mathrm{Mm} \cdot \mathrm{Cm}) \cdot \theta \mathrm{g} \cdots \cdots \cdots \cdots \cdot(19)
\end{aligned}
$$

(18), (19)式をまとめると, 次式が得られる。

$$
\begin{aligned}
& \mathrm{dx}_{1} / \mathrm{dt}=\mathrm{A}_{11} \mathrm{x}_{1}+\mathrm{A}_{12} \mathrm{x}_{2}+\mathrm{B}_{11} \mathrm{u}_{1} \\
& \mathrm{dx}_{2} / \mathrm{dt}=\mathrm{A}_{21} \mathrm{x}_{1}+\mathrm{A}_{22} \mathrm{x}_{2}+\mathrm{B}_{22} \mathrm{u}_{2} \\
& \mathrm{~A}_{11}=-(\mathrm{Cps} \cdot \mathrm{Fs}+\alpha \mathrm{ms} \cdot \mathrm{Ams}) /(\mathrm{Vs} \cdot \gamma \mathrm{s} \cdot \mathrm{Cps}) \\
& \mathrm{A}_{12}=\alpha \mathrm{ms} \cdot \mathrm{Ams} /(\mathrm{Vs} \cdot \gamma \mathrm{s} \cdot \mathrm{Cps}) \\
& \mathrm{A}_{21}=\alpha \mathrm{ms} \cdot \mathrm{Ams} /(\mathrm{Mm} \cdot \mathrm{Cm}) \\
& \mathrm{A}_{22}=-(\alpha \mathrm{gm} \cdot \mathrm{Agm}+\alpha \mathrm{ms} \cdot \mathrm{Ams}) /(\mathrm{Mm} \cdot \mathrm{Cm}) \\
& \mathrm{B}_{11}=\mathrm{Fs} /(\mathrm{Vs} \cdot \gamma \mathrm{s} \cdot \mathrm{Cps}) \\
& \mathrm{B}_{22}=(\alpha \mathrm{gm} \cdot \mathrm{Agm}) /(\mathrm{Mm} \cdot \mathrm{Cm}) \\
& \mathrm{x}_{1}=\theta \mathrm{s} \\
& \mathrm{x}_{2}=\theta \mathrm{m} \\
& \mathrm{u}_{1}=\mathrm{H} \sin -\mathrm{Hs}_{0} \\
& \mathrm{u}_{2}=\theta \mathrm{g}
\end{aligned}
$$


$\mathrm{B}_{\mathrm{ij}}$ : 駆動マトリクスの要素

(20)，(21)式をマトリクス表現で表すと，次式が得られる。

$$
\mathrm{d} \mathbf{x}, \mathrm{i} / \mathrm{dt}=\mathbf{A}, \mathrm{i} \cdot \mathbf{x}, \mathrm{i}+\mathbf{B}, \mathrm{i} \cdot \mathbf{u}, \mathrm{i}
$$

ここで,

$\mathbf{x}, \mathrm{i}=\left(\mathrm{x}_{1}, \mathrm{i} \quad \mathrm{x}_{2}, \mathrm{i}\right)^{\mathrm{T}}:$ 状態ベクトル

$\mathbf{u}, \mathrm{i}=\left(\mathrm{u}_{1}, \mathrm{i} \quad \mathrm{u}_{2}, \mathrm{i}\right)^{\mathrm{T}}$ : 入力ベクトル

$\mathbf{A}, \mathrm{i}, \mathbf{B}, \mathrm{i}: 2 \times 2$ 次元マトリクス

$\mathrm{T}:$ 転置記号

$\mathrm{i}: \mathrm{i}$ 番目の熱交換器

なお, $(20),(21)$ 式の $\mathrm{x}_{1},(20)$ 式の $\mathrm{u}_{1}$ 及び(21)式の $\mathrm{u}_{2}$ は，測 定可能な量であり, (20), (21)式の $x_{2}$ は, 測定できない量で ある。

\section{4. 新予測モデルとカルマン・フィルタを組み合わ せた予測方式}

物理式に基づく集中定数化モデルに対して，カルマン・ フィルタ(9)を構成できる。このカルマン・フィルタにより状 態変数の值を推定し, この推定值に基づいて各熱交換器の モデルを統合して使用し, 蒸気温度の近い将来值を予測す る。これについて, 述べる。

(32)式は, 時変システムであり, 離散化すると, 次式に示 すようになる。

$\mathbf{x}, \mathrm{i}(\mathrm{k})=\Phi, \mathrm{i}(\mathrm{k}-1) \cdot \mathbf{x}, \mathrm{i}(\mathrm{k}-1)+\mathbf{H}, \mathrm{i}(\mathrm{k}-1) \cdot \mathbf{u}, \mathrm{i}(\mathrm{k}-1)$

ここで,

$\Phi, \mathrm{i}:$ 状態遷移マトリクス

$\mathbf{H}, \mathbf{i}$ : 駆動マトリクス

$\mathbf{x}, \mathrm{i}(\mathrm{k})$ : k サンプリング時点の状態量

$\mathbf{x}, \mathrm{i}(\mathrm{k}-1)$ : $(\mathrm{k}-1)$ サンプリング時点の状態量

$\mathbf{u}, \mathrm{i}(\mathrm{k}-1)$ : $(\mathrm{k}-1)$ サンプリング時点の操作量

$\mathrm{k}$ : サンプリング時刻

$\Delta \mathrm{T}:$ サンプリング周期

また，観測式は，次式で表される。

$\mathbf{y}, \mathrm{i}(\mathrm{k})=\mathbf{C}, \mathrm{i}(\mathrm{k}) \cdot \mathbf{x}, \mathrm{i}(\mathrm{k})$

ここで,

$\mathbf{y}, \mathrm{i}(\mathrm{k})$ : 観測ベクトル

$\mathbf{C , i}(\mathrm{k})$ : 観測マトリクス

(33), (34)式がプラントの動特性モデルであるが，このモデ ルは，近似式であり，必然的に誤差すなわちノイズを伴う。 また, 熱交換器のメタル温度 $\theta \mathrm{m}$ は， 3 章で述べたように, 直接計測できない。このため, ノイズが存在するプロセス のオブザーバが必要となる。このオブザーバとしてカルマ ン・フィルタを利用することにした。

ノイズが存在する場合の観測式は，次式で表される。

$\mathbf{y}, \mathrm{i}(\mathrm{k})=\mathbf{C}, \mathrm{i}(\mathrm{k}) \cdot \mathbf{x}, \mathrm{i}(\mathrm{k})+\mathbf{w}, \mathrm{i}(\mathrm{k})$ ここで,

$\mathbf{w , i}(\mathrm{k})$ : 観測ノイズ・ベクトル（ガウス性白色ノイズ）

また, 状態遷移方程式は, 次式で与えられる。

$\mathbf{x}, \mathrm{i}(\mathrm{k})=\Phi, \mathrm{i}(\mathrm{k}-1) \cdot \mathbf{x}, \mathrm{i}(\mathrm{k}-1)+\mathbf{H}, \mathrm{i}(\mathrm{k}-1) \cdot \mathbf{u}, \mathrm{i}(\mathrm{k}-1)$
(36)式は，(33)式と同じ形であるが，入力ベクトル $\mathbf{u}, \mathrm{i}$ は, 平 均值 $\mathbf{u}, \mathrm{i}$ のまわりでランダムに変化する確率過程 (ガウス性 白色ノイズ）を表している。(35), (36)式に対して, カルマ ン・フィルタを構成すると, 次式が得られ, 状態ベクトル $\mathbf{x}, \mathbf{i}$ の最尤推定值 $\mathbf{x}, \mathrm{i}$ が求められる ${ }^{(9)}$ 。

$$
\begin{aligned}
\hat{\mathbf{x}}, \mathrm{i}(\mathrm{k})= & \sim \mathbf{x}, \mathrm{i}(\mathrm{k})+\mathbf{P}, \mathrm{i}(\mathrm{k}) \cdot \mathbf{C}, \mathrm{i}^{\mathrm{T}}(\mathrm{k}) \cdot \mathbf{W}, \mathrm{i}(\mathrm{k})^{-1} \\
& \cdot\left[\mathbf{y}, \mathrm{i}(\mathrm{k})-\left\{\mathbf{C}, \mathrm{i}(\mathrm{k}) \cdot \sim \mathbf{x}, \mathrm{i}(\mathrm{k})+^{-} \mathbf{w}, \mathrm{i}(\mathrm{k})\right\}\right]
\end{aligned}
$$

ここで,

$$
\sim \mathbf{x}, \mathrm{i}(\mathrm{k})=\Phi, \mathrm{i}(\mathrm{k}-1) \cdot{ }^{\wedge} \mathbf{x}, \mathrm{i}(\mathrm{k}-1)+\mathbf{H}, \mathrm{i}(\mathrm{k}-1) \cdot{ }^{-} \mathbf{u}, \mathrm{i}(\mathrm{k}-1)
$$

$$
\begin{aligned}
\mathbf{P}, \mathrm{i}(\mathrm{k})= & \left\{\mathbf{M}, \mathrm{i}(\mathrm{k})^{-1}+\mathbf{C}, \mathrm{i}^{\mathrm{T}}(\mathrm{k}) \cdot \mathbf{W}, \mathrm{i}(\mathrm{k})^{-1} \cdot \mathbf{C}, \mathrm{i}(\mathrm{k})\right\}^{-1} \\
\mathbf{M}, \mathrm{i}(\mathrm{k})= & \Phi, \mathrm{i}(\mathrm{k}-1) \cdot \mathbf{P}, \mathrm{i}(\mathrm{k}-1) \cdot \Phi, \mathrm{i}^{\mathrm{T}}(\mathrm{k}-1) \\
& +\mathbf{H}, \mathrm{i}(\mathrm{k}-1) \cdot \mathbf{U}, \mathrm{i}(\mathrm{k}-1) \cdot \mathbf{H}, \mathrm{i}^{\mathrm{T}}(\mathrm{k}-1)
\end{aligned}
$$

$\mathbf{W}, \mathrm{i}(\mathrm{k})$ : 観測ノイズ $\mathbf{w , i}$ の共分散マトリクス

$-\mathbf{w}(\mathrm{k}), \mathrm{i}:$ 観測ノイズ $\mathbf{w}, \mathrm{i}$ の平均值

$\mathbf{U}, \mathrm{i}(\mathrm{k})$ : 入力ベクトル $\mathbf{u}, \mathrm{i}$ の共分散マトリクス

次に, 状態量 $\mathbf{x}, \mathbf{i}$ の予測であるが，これには基本的に(37) 式の繰り返し計算式である次式を用いる。

$$
\begin{aligned}
\hat{\mathbf{x}}, \mathrm{ip}(\mathrm{k}, \mathrm{j})= & \sim \mathbf{x}, \mathrm{i}(\mathrm{k}, \mathrm{j})+\mathbf{P}, \mathrm{i}(\mathrm{k}) \cdot \mathbf{C}, \mathrm{i}^{\mathrm{T}}(\mathrm{k}) \cdot \mathbf{W}, \mathrm{i}(\mathrm{k})^{-1} \\
& \cdot\left[\mathbf{y}, \mathrm{i}(\mathrm{k})-\left\{\mathbf{C}, \mathrm{i}(\mathrm{k}) \cdot \sim \mathbf{x}, \mathrm{i}(\mathrm{k})+^{-} \mathbf{w}, \mathrm{i}(\mathrm{k})\right\}\right] \\
\sim & \\
\mathbf{x}, \mathrm{ip}(\mathrm{k}, \mathrm{j})= & \Phi, \mathrm{i}(\mathrm{k}-1) \cdot{ }^{\hat{x}}, \mathrm{ip}(\mathrm{k}, \mathrm{j}-1) \\
& +\mathbf{H}, \mathrm{i}(\mathrm{k}-1) \cdot{ }^{-} \mathbf{u}, \mathrm{i}(\mathrm{k}-1)
\end{aligned}
$$$$
\hat{x}, \mathrm{ip}(\mathrm{k}, 0)=\hat{x}, \mathrm{i}(\mathrm{k})
$$

ここで,

$\hat{x}, \mathrm{ip}(\mathrm{k}, \mathrm{j}): \mathrm{k}$ サンプリング時の $\mathrm{j}$ サンプリング先の状態ベ クトルの予測值

(41)式において, $\mathbf{P}, \mathrm{i}(\mathrm{k}) \cdot \mathbf{C}, \mathrm{i}^{\mathrm{T}}(\mathrm{k}) \cdot \mathbf{W}, \mathrm{i}(\mathrm{k})^{-1} \cdot[\mathbf{y}, \mathrm{i}(\mathrm{k})-$ $\left.\left\{\mathbf{C}, \mathrm{i}(\mathrm{k}) ・ \sim \mathbf{x}, \mathrm{i}(\mathrm{k}){ }^{-}{ }^{-} \mathbf{w}, \mathrm{i}(\mathrm{k})\right\}\right]$ は, モデル誤差の補償項であり, バイアス的に加わるものと仮定している。また, 前段熱交 換器(i-1)の出口蒸気温度 $\theta \mathrm{s}, \mathrm{i}-1$ の変動は, (44)式により前 段熱交換器(i-1)の出口蒸気エンタルピ Hs,i-1 の変動として 反映される。更に, (45)式に示すむだ時間要素を介して, (46) 式により当該熱交換器(i)の入口蒸気エンタルピ Hsin,i の変 動として反映され, 予測值を求める。

$$
\begin{aligned}
& \mathrm{Hs}, \mathrm{i}-1=\mathrm{Hs}, \mathrm{i}-1(\theta \mathrm{s}, \mathrm{i}-1, \mathrm{Ps}, \mathrm{i}-1) \\
& \mathrm{Hsin}, \mathrm{i}=\exp (-\mathrm{Ls}) \cdot \mathrm{Hs}, \mathrm{i}-1
\end{aligned}
$$

なお, 状態遷移マトリクス, 駆動マトリクスなどのパラメ 一タは, 蒸気流量などプロセス量に依存して変化するが, 予測中は，予測開始時の值を使用する。

前章で説明した熱交換器のモデル式に基づいて, 各熱交 換器単体の予測モデルをブロック線図で表すと, 図 6 に示 すようになる。すなわち, 熱交換器単体モデルは, 燃料流 量 Ff, 空気流量 Fa 及びガス再循環流量 Fgrf と, 火炉水壁熱 吸収量 Qww 及び火炉水壁以外のガス側上流熱交換器の総熱 吸収量 $\mathrm{Q}_{\mathrm{HEX}}$ とに基づいて, ガス温度 $\theta$ gIN を計算するガス 温度計算モデルと, 熱交換器の入口蒸気温度 $\theta \operatorname{sIN}$ を管内部 流体（水・蒸気）の入口エンタルピ $\mathrm{HsIN}$ に変換する変換部 と, エンタルピ, 蒸気流量及びガス温度に対する, それぞ 


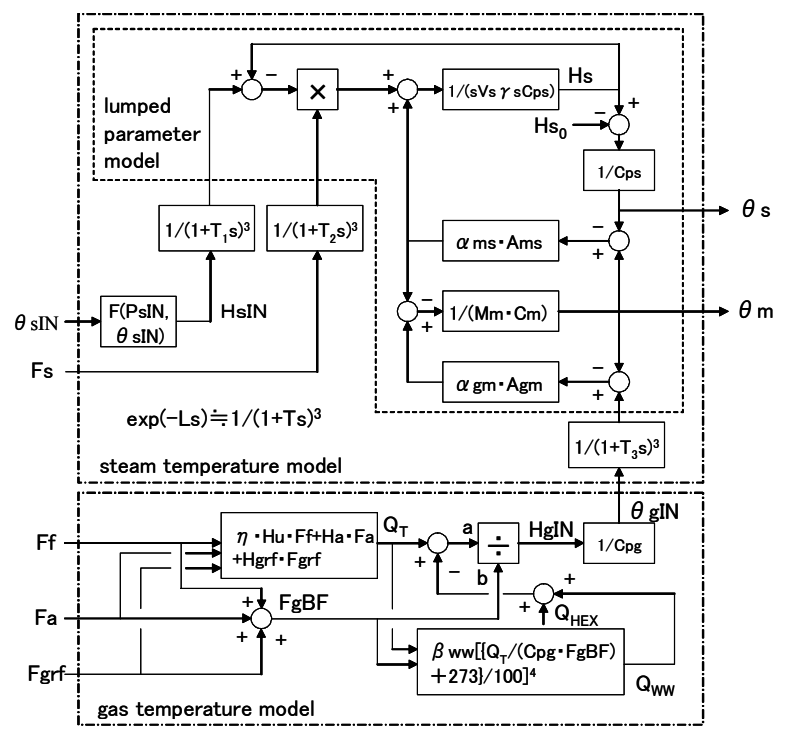

図 6 各熱交換器単体の予測モデルのブロック線図

Fig. 6. Block diagram of each prediction model for heat exchanger.

れ 3 次遅れにより近似的に与える無駄時間要素と, 集中定 数化モデルとで構成される。

\section{5. 予測制御}

予測制御システムは, 図 7 に示寸ように, 目標值予測シ ステム, 蒸気温度予測システム, 操作量決定システムから 構成される。

目標值予測システムは, 蒸気温度の目標值の $\mathrm{n}$ サンプリ ング周期先の将来值を次式により予測する。ここでは, 1 次 過熱器出口蒸気温度, 2 次過熱器出口蒸気温度, 主蒸気温度 及び再熱蒸気温度の目標值を次式により算出する。

$$
\begin{aligned}
& \mathrm{r}_{1}(\mathrm{k}, \mathrm{n})=\mathrm{r}_{1}(\mathrm{k})+\mathrm{a}_{1}(\mathrm{k}) \cdot \mathrm{n} \cdot \Delta \mathrm{T} \\
& \mathrm{r}_{2}(\mathrm{k}, \mathrm{n})=\mathrm{r}_{2}(\mathrm{k})+\mathrm{a}_{2}(\mathrm{k}) \cdot \mathrm{n} \cdot \Delta \mathrm{T} \\
& \mathrm{r}_{3}(\mathrm{k}, \mathrm{n})=\mathrm{r}_{3}(\mathrm{k})+\mathrm{a}_{3}(\mathrm{k}) \cdot \mathrm{n} \cdot \Delta \mathrm{T} \\
& \mathrm{r}_{4}(\mathrm{k}, \mathrm{n})=\mathrm{r}_{4}(\mathrm{k})+\mathrm{a}_{4}(\mathrm{k}) \cdot \mathrm{n} \cdot \Delta \mathrm{T}
\end{aligned}
$$

なお，蒸気温度の目標值の予測值は，プラントの状態に応 じてプラントの運転基準に従って計算される。 ここで，

$\mathrm{r}_{1}(\mathrm{k}, \mathrm{n})$ : 現在時点 $\mathrm{k}$ において, 1 次過熱器出口蒸気温度 $\theta \mathrm{s}_{1 \mathrm{SH}}$ の目標值 $\mathrm{r}_{1}$ の $\mathrm{n}$ サンプリング周期先の予測值 $\mathrm{r}_{2}(\mathrm{k}, \mathrm{n})$ : 現在時点 $\mathrm{k}$ において, 2 次過熱器出口蒸気温度 $\theta \mathrm{s}_{2 \mathrm{SH}}$ の目標值 $\mathrm{r}_{2}$ の $\mathrm{n}$ サンプリング周期先の予測值 $\mathrm{r}_{3}(\mathrm{k}, \mathrm{n})$ : 現在時点 $\mathrm{k}$ において, 3 次過熱器出口蒸気温度

（主蒸気温度） $\theta \mathrm{s}_{\mathrm{MS}}$ の目標值 $\mathrm{r}_{3}$ の $\mathrm{n}$ サンプリング周 期先の予測值

$\mathrm{r}_{4}(\mathrm{k}, \mathrm{n})$ : 現在時点 $\mathrm{k}$ において, 2 次再熱熱器出口蒸気温度 (再熱蒸気温度) $\theta \mathrm{s}_{\mathrm{RS}}$ の目標值 $\mathrm{r}_{4}$ の $\mathrm{n}$ サンプリグ周期 先の予測值

$r_{i}(k)$ : 蒸気温度の目標值 $r_{i}$ の現在時点における值 $(i=1 \sim 4)$

$a_{i}(k)$ : 蒝気温度の目標值 $r_{i}$ の現在時点における変化率 $(\mathrm{i}=1 \sim 4)$

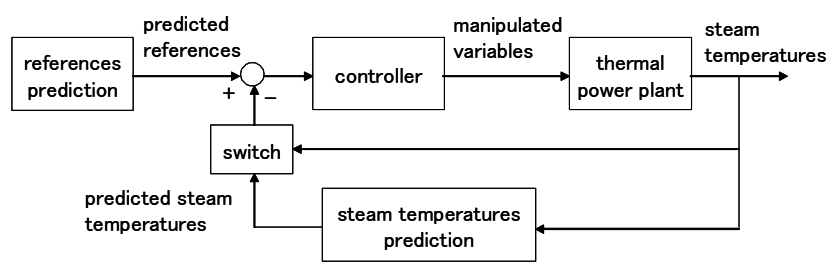

図 7 予測制御システム

Fig. 7. Prediction control system of thermal power plant.

$\Delta \mathrm{T}:$ サンプリング周期

蒸気温度予測システムは, 蒸気温度系のモデル, すなわ ち, 蒸気温度予測モデルを使用して, 蒸気温度の $\mathrm{n}$ サンプ リング周期先の将来值を予測する。この蒸気温度予測モデ ルと予測方式については，それぞれ，3 章と 4 章で述べた。

操作量決定システムは, 目標值の $\mathrm{n}$ サンプリング周期先 の予測值と蒸気温度の $\mathrm{n}$ サンプリング周期先の予測值に基 づいて，操作量を決定する。そのアルゴリズムは，次式に 示すように，比例・積分制御アルゴリズムに準じており， 比例・積分形予測制御と呼んでいる ${ }^{(8)}$ 。

$$
\begin{aligned}
\Delta \mathrm{u}_{\mathrm{i}}(\mathrm{k})= & \mathrm{u}_{\mathrm{i}}(\mathrm{k})-\mathrm{u}_{\mathrm{i}}(\mathrm{k}-1) \\
= & \left.\mathrm{Kp}_{\mathrm{i}}\left[\left\{\mathrm{r}_{\mathrm{i}}(\mathrm{k}, \mathrm{n})-\mathrm{y}_{\mathrm{i}}(\mathrm{k}, \mathrm{n})\right\}-\left\{\mathrm{r}_{\mathrm{i}}(\mathrm{k}-1, \mathrm{n})\right\}-\mathrm{y}_{\mathrm{i}}(\mathrm{k}-1, \mathrm{n})\right]\right] \\
& +\mathrm{K}_{\mathrm{Ii}}\left\{\mathrm{r}_{\mathrm{i}}(\mathrm{k}, \mathrm{n})-\mathrm{y}_{\mathrm{i}}(\mathrm{k}, \mathrm{n})\right\} \quad(\mathrm{i}=1 \sim 4) \cdots \cdots . .(51)
\end{aligned}
$$

ここで，

$\mathrm{K}_{\mathrm{Ii}}$ : 比例ゲイン

$\mathrm{K}_{\mathrm{Ii}}:$ 積分ゲイン

$\mathrm{y}_{1}(\mathrm{k}, \mathrm{n})$ : 現在時点 $\mathrm{k}$ において, 1 次過熱器出口蒸気温度 $\theta \mathrm{s}_{1 \mathrm{SH}}$ の $\mathrm{n}$ サンプリング周期先の予測值

$\mathrm{y}_{2}(\mathrm{k}, \mathrm{n})$ : 現在時点 $\mathrm{k}$ において, 2 次過熱器出口蒸気温度 $\theta \mathrm{s}_{2 \mathrm{SH}}$ の $\mathrm{n}$ サンプリング周期先の予測值

$\mathrm{y}_{3}(\mathrm{k}, \mathrm{n})$ : 現在時点 $\mathrm{k}$ において, 3 次過熱器出口蒸気温度 $\theta \mathrm{s}_{\mathrm{MS}}$ の $\mathrm{n}$ サンプリング周期先の予測值

$\mathrm{y}_{4}(\mathrm{k}, \mathrm{n})$ : 現在時点 $\mathrm{k}$ において，再熱熱器出口蒸気温度 $\theta \mathrm{s}_{\mathrm{RS}}$ の $\mathrm{n}$ サンプリング周期先の予測值

$\Delta \mathrm{u}_{\mathrm{i}}(\mathrm{k})$ : 現在時点における操作量 $\mathrm{u}_{\mathrm{i}}(\mathrm{k})$ の変化分

$\mathrm{i}: \mathrm{i}$ 番目の操作量

なお，本制御方式では，予測制御装置と通常制御装置を 並置し，蒸気温度の計測值と推定值の誤差が予め定めた範 囲に入るときのみ予測制御を実施するようにしている。図 7 のスイッチは，この目的のために設けられている。誤差が 大きい場合には, 通常の PI（比例・積分）制御を行い, 誤 差が小さくなると, 予測制御に切り替える。制御パラメー 夕は，予測制御と通常制御で原則同じ值を用いている。こ れは，比例・積分形予測制御では制御パラメータが多少最 適值からずれても，制御特性が余り変わらないからであ る ${ }^{(8)}$ 。ただ，予測值と実際の制御量の間で変動の振幅が異な る場合は，予測值の制御偏差に係数を掛けて，実際の制御 量の偏差と同じ程度になるように調整する。

\section{6. シミュレーション評価}

本予測制御方式の効果を確認するために, 変圧貫流ボイ 


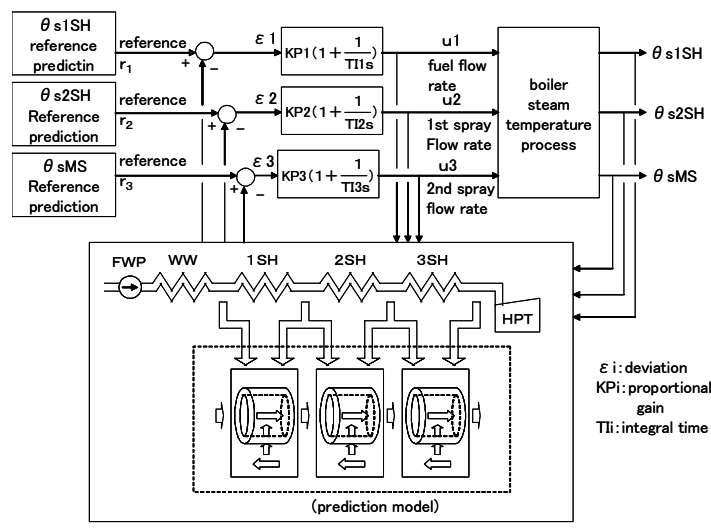

図 8 蒸気温度予測制御系の構成

Fig. 8. Structure of steam temparature prediction control system.

ラの実規模シミュレータを用いてシミュレーションを実施 した。本シミュレータは, 図 1 に示す火力プラント本体と 図 2 に示す火力プラント制御システムを模擬している。火 カプラント本体は, 質量保存の法則, エネルギ保存の法則 及び運動量保存の法則に基づいて表される物理式により模 擬している。図 8 は，実規模シミュレータのうちで，過熱 器側の蒸気温度予測制御系の夕を取り出して，その構成を 示したものであり, 図 9,10 は, 負荷指令(LD)を 50\%〜 75\% まで $5 \% /$ 分でランプ変化させたときのシミュレーション 結果を示す。

図 9 は, 現在值を用いたフィードバック制御（PID 制御） 時の予測モデルの評価結果を示す。この場合, 火力プラン トは，PID 制御により制御され，予測モデルは，サンプリン グ周期（5 秒）毎に，操作量が保持されるとして，5 分先の 蒸気温度を予測するが，予測值は制御には使用されない。 図において, 1 次過熱器出口温度 $(\theta \mathrm{s} 1 \mathrm{SH}), 2$ 次過熱器出口 蒸気温度 $(\theta \mathrm{s} 2 \mathrm{SH})$ 及び主蒸気温度 $(\theta \mathrm{sMS})$ の 5 分先の蒸気温 度の予測值を破線で示し，実温度を実線で示す。この図か ら分かるように，主蒸気温度 $(\theta \mathrm{sMS})$ の予測值は，実温度の ほぼ 4 分〜5 分くらい前に変化しており，良好な予測值が得 られている。なお, 1 次過熱器出口蒸気温度 $(\theta \mathrm{s} 1 \mathrm{SH})$ の予測 值は，モデルの構成上，単段の熱交換器予測モデルで予測 したものと見なせ, 実温度のほぼ 1 分 30 秒〜 40 秒くらい前 に変化している。このことから，多段熱交換器は，単段と 比較して，予測性能が向上することが分かる。ここで，時 間関数 $\mathrm{f}(\mathrm{t})$ のラプラス変換は, $\mathrm{F}(\mathrm{s})$ で表され， $\mathrm{f}(\mathrm{t})$ の予測值 $\mathrm{f}(\mathrm{t}+1) \quad(1$ : 予測時間 $)$ のラプラス変換は， $\mathrm{F}(\mathrm{s}) \exp (1 \mathrm{~s})$ で表さ れる。図 9, 10 での実温度と温度の予測值は, $\mathrm{f}(\mathrm{t})$ と予測值 $\mathrm{f}(\mathrm{t}+1)$ と同じ関係を表しており，予測值 $\mathrm{f}(\mathrm{t}+\mathrm{l})$ は， $\mathrm{f}(\mathrm{t})$ より 1 秒 早く変動することを表している。

予測時間であるが，操作量の動きに制限がある場合，予 測時間は長ければ長い方が望ましい。蒸気温度制御の場合, 可能なら 10 分程度の值に設定したいが，3 段の熱交換器で は，5 分以上の予測時間を設定しても，得られる予測值は， 4 分〜 5 分先が限界である。今後, 火炉水壁まで含めて, よ

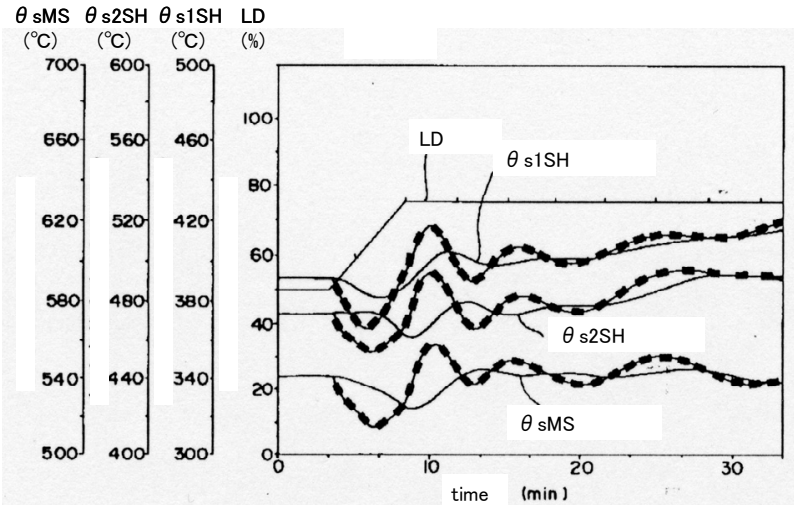

図 9 フィードバック制御（PID 制御）時の予測モデル の評価結果

Fig. 9. Simulation results of prediction model for PID control system.

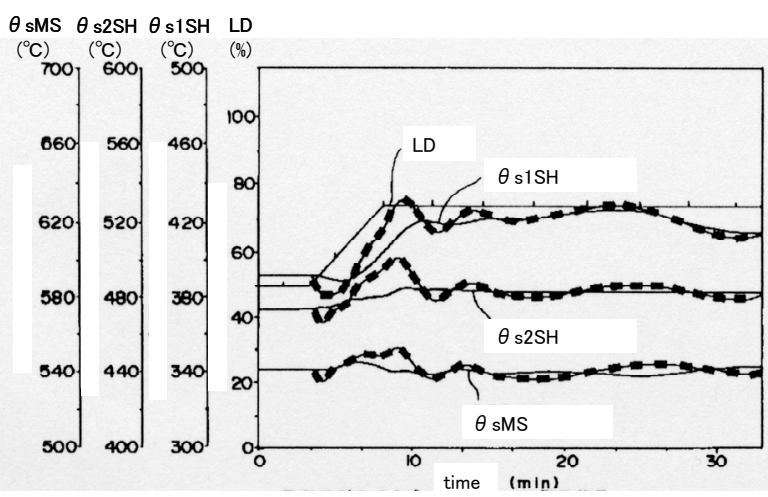

図 10 予測值を用いた予測制御の評価結果

Fig. 10. Simulation results of prediction control system.

り多段の熱交換器予測モデルを構築して, 予測時間が延び る方法を検討する必要がある。

図 10 は, 予測值を用いた予測制御の評価結果を示す。評 価の方法は, 図 9 の場合と同じである。この場合, 火力プ ラントは, 比例・積分形予測制御により制御され，予測モ デルは, サンプリング周期毎に, 操作量が保持されるとし て, 5 分先の蒸気温度を予測し, その予測值に基づいて, 予 測制御されている。また, 図 9 と同様に, 1 次過熱器出口蒸 気温度 $(\theta \mathrm{s} 1 \mathrm{SH}), 2$ 次過熱器出口蒸気温度 $(\theta \mathrm{s} 2 \mathrm{SH})$ 及び主蒸 気温度 $(\theta \mathrm{sMS})$ の 5 分先の蒸気温度の予測值を破線で示し, 実温度を実線で示す。図 10 から分かるように, 主蒸気温度 $(\theta \mathrm{sMS})$ の変動が, 現在值フィードバック制御時と比べて, $1 / 3 \sim 1 / 2$ に抑えられており, 大いに制御性が向上してい る。

\section{7. 考 察}

〈7·1〉多段熱交換器予測モデルとカルマン・フィルタ の構成 3 章で述べたように, 蒸気温度予測モデルは, 分 布定数系である火力プラントの各熱交換器のモデルを無駄 時間要素と物理式に基づく集中定数化モデルとの組み合わ 
せにより構成し，それらの各熱交換器のモデルを結合して 多段熱交換器モデルを構成している。また，物理式に基づ く集中定数化モデルに対して, カルマン・フィルタが構成 される。このカルマン・フィルタにより状態変数の值を推 定し, この推定值に基づいて各熱交換器のモデルを統合し て使用し, 多段熱交換器の蒸気温度の近い将来值を予測し ている。

本方式の特徴は, カルマン・フィルタを構成するマトリ クスの次数が小さくなり, 計算負荷が小さくなることであ る。また, 火力プラントは, 種々の熱交換器構成が考えら れ, プラントにより熱交換器の構成が異なるが, それらに 容易に対応できる。

今後, 分布定数系である火力プラントの各熱交換器のモ デルを複数に分割された物理式に基づく集中定数化モデル の組み合わせにより構成し, それらの各熱交換器のモデル を結合して構成することが考えられる。この場合でも, 複 数に分割された物理式に基づく集中定数化モデルに対し て, カルマン・フィルタが構成できる。このカルマン・フ イルタにより状態変数の值を推定し, この推定值に基づい て各熱交換器のモデルを統合して使用し, 多段熱交換器の 蒸気温度の近い将来值を予測できる。それにより，本方式 と同様に，カルマン・フィルタを構成するマトリクスの次 数が余り大きくならず，計算負荷が小さくなると考えられ る。また, プラントにより熱交換器の構成が異なっても, それらに容易に対応できる。

〈7·2〉 経年変化への対応＼cjkstart本論文では, サンプリン グ周期毎に, 蒸気温度予測開始時の状態量の初期值及びモ デル化誤差の推定のためにカルマン・フィルタを利用して いる。実規模シミュレータを使用したシミュレーションで は, シミュレータと予測モデルにおいて, 対応する各熱交 換器の定常状態の蒸気温度が略一致するように，モデルの パラメータを調整して, シミュレーションを実施したため, モデル化誤差が小さく, 良好な予測值が得られている。し かしながら, 石炭焚き火力プラントは, 経年変化や炭種の 違いなどにより実プラントの特性が時間と共に変化する。 このため，実プラントと予測モデルにおいて，対応する各 熱交換器の定常状態の蒸気温度を略一致させる調整機構が 必要になる。

調整機構として，下記の 2 つ方式が考えられる。

(1) 積分補正による予測モデルのパラメータ調整方式 蒸気温度の計測值とモデルによる 1 段予測值との差は, モデル化による誤差であり，この予測誤差が定常状態にお いて零になるように, 各熱交換器モデルのガス温度 $\theta$ gin を 次式により補正する。

$\theta \operatorname{gin}(\mathrm{k})=\theta \operatorname{gin}(\mathrm{k}-1)+\Delta \theta \operatorname{gin}(\mathrm{k})$

$$
\begin{aligned}
= & \theta \operatorname{gin}(\mathrm{k}-1) \\
& +\mathrm{K} \cdot\left[\mathbf{y}(\mathrm{k})-\left\{\mathbf{C}(\mathrm{k}) \cdot \sim \mathbf{x}(\mathrm{k}){ }^{+-} \mathbf{w}(\mathrm{k})\right\}\right]
\end{aligned}
$$

ここで,

$\mathrm{K}:$ 積分ゲイン

この方式は，補正の調整速度が，少し遅いが，実プラン
トでのテストで，実プラントと予測モデルにおいて，対応 する各熱交換器の定常状態での蒸気温度が一致することを 確認している。ただ，シミュレータと予測モデルにおいて， 対応する各熱交換器の定常状態での蒸気温度が略一致する ように，事前にモデルのパラメータを調整できる場合と比 べると，少し予測性能が低下寸る。このため，この方式は， 今後，改良が必要である。

(2) バイアス形モデル化誤差補正による予測モデルの パラメータ調整方式

モデル誤差として, バイアス形モデル化誤差 $\mathbf{d}$ を仮定し, (33)式の右辺にモデル化誤差 $\mathbf{d}$ を加えると共に, モデル化誤 差 $\mathbf{d}$ の状態遷移式が次式で与えられるものとする。

$$
\mathbf{x}(\mathrm{k})=\Phi(\mathrm{k}-1) \cdot \mathbf{x}(\mathrm{k}-1)+\mathbf{H}(\mathrm{k}-1) \cdot \mathbf{u}(\mathrm{k}-1)+\mathbf{d}(\mathrm{k}-1)
$$

$\mathbf{d}(\mathrm{k})=\mathbf{d}(\mathrm{k}-1)+\mathbf{v}(\mathrm{k}-1)$

ここで,

d $(\mathrm{k}-1):(\mathrm{k}-1)$ サンプリング時点のモデル化誤差バイア 又值

$\mathbf{v}(\mathrm{k}-1):(\mathrm{k}-1)$ サンプリング時点のモデル化誤差ノイズ 拡大状態変数 $\mathbf{z}$ を導入すると, 次式が得られる。

$\mathbf{z}(\mathrm{k})=\Phi^{-}(\mathrm{k}-1) \cdot \mathbf{z}(\mathrm{k}-1)+\mathbf{H}^{-}(\mathrm{k}-1) \cdot \mathbf{u}(\mathrm{k}-1)$

ここで,

$\Phi^{-}$: 拡大系の状態遷移マトリクス

$\mathbf{H}^{-}$: 拡大系の駆動マトリクス

$\mathbf{z}(\mathrm{k}-1)$ : $(\mathrm{k}-1)$ サンプリング時点の拡大系の状態量

$\mathbf{u}(\mathrm{k}-1):(\mathrm{k}-1)$ サンプリング時点の拡大系の操作量

$\Phi^{-}(\mathrm{k}-1)=\left[\begin{array}{ll}\Phi_{1}(\mathrm{k}-1) & \Phi_{2}(\mathrm{k}-1)\end{array}\right]^{\mathrm{T}}$

$\Phi_{1}(\mathrm{k}-1)=[\Phi(\mathrm{k}-1) \mathrm{I}]$

$\Phi_{2}(\mathrm{k}-1)=\left[\begin{array}{ll}\mathbf{0} & \mathrm{I}\end{array}\right]$

$\mathbf{H}^{-}(\mathrm{k}-1)=\left[\begin{array}{ll}\mathbf{H}(\mathrm{k}-1) & \mathbf{0}\end{array}\right]^{\mathrm{T}}$

$\mathbf{z}(\mathrm{k}-1)=\left[\begin{array}{ll}\mathbf{x}(\mathrm{k}-1) & \mathbf{d}(\mathrm{k}-1)\end{array}\right]^{\mathrm{T}}$

また，観測式は，次式で表される。

$\mathbf{y}(\mathrm{k})=\mathbf{C}^{-}(\mathrm{k}) \cdot \mathbf{z}(\mathrm{k})+\mathbf{w}(\mathrm{k})$

ここで,

$\mathbf{y}(\mathrm{k})$ : 拡大系の観測ベクトル

$\mathbf{w}(\mathrm{k})$ : 拡大系の観測ノイズ・ベクトル

$\mathrm{C}^{-}(\mathrm{k})$ : 拡大系の観測マトリクス

$\mathbf{C}^{-}(\mathrm{k}-1)=\left[\begin{array}{ll}\mathbf{C}(\mathrm{k}-1) & \mathbf{0}\end{array}\right]$

(55), (61)式に対して, カルマン・フィルタを構成すると, 次式が得られ, 状態ベクトル $\mathbf{z}$ の最尤推定值^ $\mathbf{z}$ が求められ $3^{(9)}$ 。

$$
\begin{aligned}
& { }^{\wedge} \mathbf{z}(\mathrm{k})=\sim \mathbf{z}(\mathrm{k})+\mathbf{P}^{-}(\mathrm{k}) \cdot \mathbf{C}^{-\mathrm{T}}(\mathrm{k}) \cdot \mathbf{W}(\mathrm{k})^{-1} \\
& \cdot\left[\mathbf{y}(\mathrm{k})-\left\{\mathbf{C}^{-}(\mathrm{k}) \cdot \sim \mathbf{z}(\mathrm{k})+^{-} \mathbf{w}(\mathrm{k})\right\}\right] \\
& { }^{\sim} \mathbf{z}(\mathrm{k})=\Phi(\mathrm{k}-1) \cdot{ }^{\wedge} \mathbf{z}(\mathrm{k}-1)+\mathbf{H}(\mathrm{k}-1) \cdot{ }^{-} \mathbf{u}(\mathrm{k}-1) \\
& \mathbf{P}^{-}(\mathrm{k})=\left\{\mathbf{M}^{-}(\mathrm{k})^{-1}+\mathbf{C}^{-\mathrm{T}}(\mathrm{k}) \cdot \mathbf{W}(\mathrm{k})^{-1} \cdot \mathbf{C}^{-}(\mathrm{k})\right\}^{-1} \\
& \mathbf{M}^{-}(\mathrm{k})=\Phi^{-}(\mathrm{k}-1) \cdot \mathbf{P}^{-}(\mathrm{k}-1) \cdot \Phi^{-\mathrm{T}}(\mathrm{k}-1) \\
& +\mathbf{H}^{-}(\mathrm{k}-1) \cdot \mathbf{U}^{-}(\mathrm{k}-1) \cdot \mathbf{H}^{-\mathrm{T}}(\mathrm{k}-1)
\end{aligned}
$$


今後，この(2)の方式についても検討する必要がある。

〈7·3〉 カルマン・フィルタにおけるノイズの扱い

本論文では，ノイズは，ガウス性の白色ノイズとして扱 っている。カルマン・フィルタの理論では, ノイズがガウ ス性の白色ノイズの場合, 推定值は, 最尤推定值で, かつ, 最小分散推定値になる。

現実の世界では，ノイズがガウス性の白色ノイズとなる ケースは，それ程多くなく，ノイズが非ガウス性の白色ノ イズとなる方が多いと思われる。このため，ノイズがガウ ス性の白色ノイズと仮定するのは，あくまでも近似である。 また，ノイズが非ガウス性の白色ノイズであっても，カル マン・フィルタの漸化式は，ノイズがガウス性の白色ノイ ズの場合と同じであり，推定值は，最小分散推定值になる。 仮定と現実の乘離が大きいと推定精度が落ちるが，本論文 では，良好な予測精度が得られており，ノイズがガウス性 の白色ノイズと仮定しても，十分実用に耐えるものと考え られる。なお，ノイズの分散值であるが，現実の蒸気温度 の計測值は, 殆どノイズがなく, 計測器の精度に基づいて, 分散值を設定している。

上記のような適用環境においては，ノイズの分散值が， 小さく, 計測值とモデルのみによる推定值に差が生じるの は，殆どがモデル化誤差と考えられる。このため，予測に おいて，このモデル化誤差をバイアス值として，加えるよ うにして，良好な予測值が得られている。実際，このモデ ル化誤差を加えないと, 予測值の精度が，悪くなることを 確認している。

なお，予測では，著者等の考えで, 上記のようにカルマ ン・フィルタをモデル化誤差の同定器として使用している が，モデル化誤差によるノイズ環境下でのオブザーバとし ては，一般的な状態推定器として使用している。すなわち, 蒸気温度とメタル温度の推定器として使用している。従っ て，カルマン・フィルタの旨い使用方法を考えれば，応用 領域がより広がるものと考えられる。

また，システムのノイズの分散值が，状態推定の精度に 影響を与えることは良く知られており，最尤推定法等が提 案されている(20)(21)。今後, 最尤推定法等を用いてノイズの 時間的不均一性（高負荷時のノイズと低負荷時のノイズの 違い）について検討する必要がある。

\section{8. 結 言}

多段熱交換器モデルを用いた火力発電プラント蒸気温度 予測制御方式について検討した。

本制御方式は, (1)蒸気温度の将来の変化予測にプラント の動特性モデルを利用している，(2)この動特性モデルは, 単段の熱交換器の物理式モデルをカスケードに接続して, 上流側の熱交換器の蒸気温度变化が下流側の蒸気温度変化 に反映するように統合して予測に使用する，(3)単段の熱交 換器モデルは，むだ時間要素と集中定数化モデルで構成さ れる，(4)この動特性モデルのパラメータは，起動時や負荷 追従運転時に大幅に変化するので，逐次同定により適応修
正している，点に特徵がある。

変圧貫流ボイラの実規模シミュレータを用いてシミュレ ーション評価した結果, 現在值を用いたフィードバック制 御（PID 制御）時の予測では, 主蒸気温度の予測值は, 実温 度のほぼ 4 分〜 5 分前に変化しており, 良好な予測值が得ら れていることが分かった。

また，予測值を用いた予測制御では，主蒸気温度の変動 が，現在值フィードバック制御時と比べて， $1 / 3 \sim 1 / 2$ に 抑えられて，大いに制御性が向上することが分かった。

(平成 18 年 12 月 5 日受付，平成 19 年 3 月 27 日再受付)

\section{文献}

(1) 野村政英, 他:「分散形ディジタル・ボイラ制御装置」, 昭 55 電気学 会全大, $1196(1980)$

(2) M. Iioka, Y. Sato, et al. : "Digital Control System for Coal Fired Power Plants", Hitachi Review, Vol.23, No.6, pp.313-316 (1980)

（3）佐藤美雄・西村 昭:「火力発電プラントの計算機制御の現状と将来 展望」，エネルギー・資源, Vol.3, No.2, pp.62-72 (1982)

(4) 東 敏彦·飯岡康弘・佐藤美雄: ‘火力発電所全ディジタル制御装置」, 日立評論, Vol.64, No.10, pp.69-72 (1982)

(5) 佐藤美雄, 他:「カルマン・フィルタによるボイラ蒸気温度予測制御」, 第 18 回 SICE（計測自動制御学会）学術講演会，1201，8月 29 日～ 9月 1 日 (1979)

(6) Y. Sato, et al. : "Steam Temperature Prediction Control for Thermal Power Plant", IEEE/PES 1984 Winter Meeting, Dallas, Texas. U.S.A. January 29-February 3

(7) Y. Sato, et al. : "Steam Temperature Prediction Control for Thermal Power Plant", IEEE Trans. on Power Apparatus and Syetems, Vol.PAS-103, No.9, pp.2382-2387 (1984-9)

（8）野村政英·佐藤美雄: 「比例・積分形予測制御方式」, 電学論, Vol.105-C, No.6, pp.125-132 (1985-6)

（9）有本 卓：「カルマン・フィルタ」, 71, 産業図書 (1977)

(10) H. Nakamura, et al. : "Statistical Identification for Optimal Control of Supercritical Thermal Power Plants", Automatica, Vol.17, No.1, pp.143-155 (1981)

(11) M. Nomura, et al. : "Adaptive Optimal Control of Steam Temperatures for Thermal Power Plants", IEEE Trans. on Energy Conversion, Vol.4, No.1, pp.25-33 (1989-3)

(12) S. Matsumura, et al. : "Adaptive control for the Steam Temperature of Thermal Power Plant", IFAC Control Engineering Practice, Vol.2, No.4, pp.567-575 (1994)

(13) Y. Toyoda, et al. : "The Nonlinear System Identification Method for the Advanced Control of the Fossil Power Plants", IFAC Symposium on System Identification, Fukuoka, Japan (1997)

(14) H. Peng, et al. : "A Nonlinear Exponential ARX Model Based Multivariable Generalized Predictive Control Strategy for Thermal Power Plants", IEEE Trans. on Control Systems Technology, Vol.10, No.2, pp.49-56 (2002)

(15) Y. Sato, et al. : "Computer Control System for Thermal Power Plant Boiler Startup", Transactions of SICE, Vol.12, No.4, pp.475-481 (1976-8) (in Japanese)

佐藤美雄, 他 :「ボイラ起動の計算機制御システム」, 計測自動制御 学会論文集, 12, 4, pp.475-481 (1976-8)

(16) S. Isomura : "Supercritical Sliding Pressure Boiler Steam Temperature Dynamics", Trans. on C of JASME, Vol.61, No.581, pp.49-56 (1995-1) (in Japanese)

磯村修一: 「超臨界圧変圧ボイラの蒸気温度動特性」, 日本機械学会 論文集 (C 編)， 61, 581, pp.49-56 (1995-1)

(17) S. Isomura, et al. : "Application of Super-Real-Time Simulation Control (SRTC) by Parallel Processing to Boiler Steam Temperature Control", Trans. on C of JASME, Vol.61, No.582, pp.633-640 (1995-2) (in Japanese) 磯村修一, 他:「並列処理による超リアルタイムシミュレーションコ ントロール(SRTC)のボイラ蒸気温度制御への応用」, 日本機械学会論 
文集 (C 編)，61, 582, pp.633-640 (1995-2)

(18) M. Rode, et al. : "Model Predictive Control for Boiler Start-up (BolierMax)", ABB Review, pp.30-36 (2003-3)

（19）豊田幸裕，他：「コンバインドサイクル発電所における Nox 低減用 SCR 制御システムへの非線形モデルベース予測制御の適用」, 計測 と制御, Vol.45, No.10, pp.475-481 (2006-10)

(20) R. K. Mehra : "Identification of Linear Dynamic Systems", Amer. Inst. Aeronaut. Astronaut. J. 9, pp.28-31 (1971)

(21) K. J. Astrom et al. : "Application of System Identification Techniques to the Determination of Ship Dynamics", In Identification of System Parameter Estimation, ed. P. Eykoff, North-Holland, pp.415-424 (1973)

野 村 政 英 （学生員）1947 年 9 月 29 日生。1972 年 3 月京 都工芸繊維大学大学院工芸学研究科電気工学

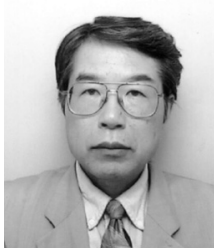
専攻修士課程修了。同年 4 月（株）日立製作所 入社。同社日立研究所にて，主として，原子力 プラント及び火カプラント計算機制御システ ムの研究に従事。2002 年 6 月（株）日立製作所 退社。2003 年 4 月茨城大学大学院理工学研究科 博士後期課程生産科学専攻入学。計測自動制御 学会, ロボット学会, 日本ファジィ学会会員。

佐 藤 美 雄 (正員) 1943 年 5 月 22 日生。1967 年 3 月横

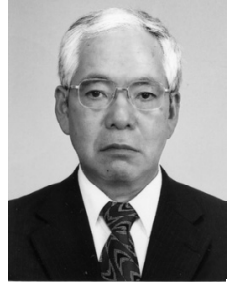
浜国立大学機械工学科卒業。同年 4 月（株）日 立製作所入社。同社日立研究所にて, 主として, 火力プラント計算機制御システムの研究に従 事。2002 年 3 月（株）日立製作所退社。計測自 動制御学会, 日本機械学会, IEEE 会員。

大 内 和 紀

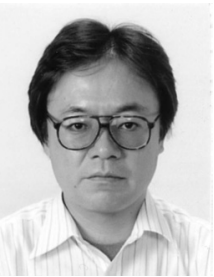

近 藤

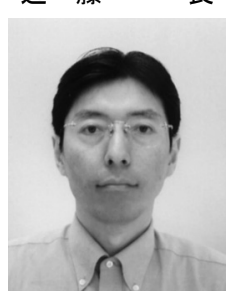

（正員） 1961 年 4 月 10 日生。1987 年 3 月東 北大学大学院工学研究科機械工学専攻修士課 程修了。同年 4 月（株）日立製作所入社。同社 日立研究所, 大甕工場にて, 主として, 火力プ ラント計算機制御システムの研究及び設計に 従事。

（非会員） 1959 年 1 月 5 日生。1986 年 3 月東 京工業大学大学院博士後期課程制御工学専攻 修了。工学博士。同年 4 月同大学工学部助手。 1990 年茨城大学工学部講師, 1991 年同助教授, 現在に至る。主として, メカニカルシステムの 制御に関する研究に従事。日本機械学会, 日本 ロボット学会会員。 